\title{
ROTINA DE TRABALHO E SUAS ADAPTAÇÕES"
}

DOI: $h$ ttp://dx.doi.org/10.18616/intcov60

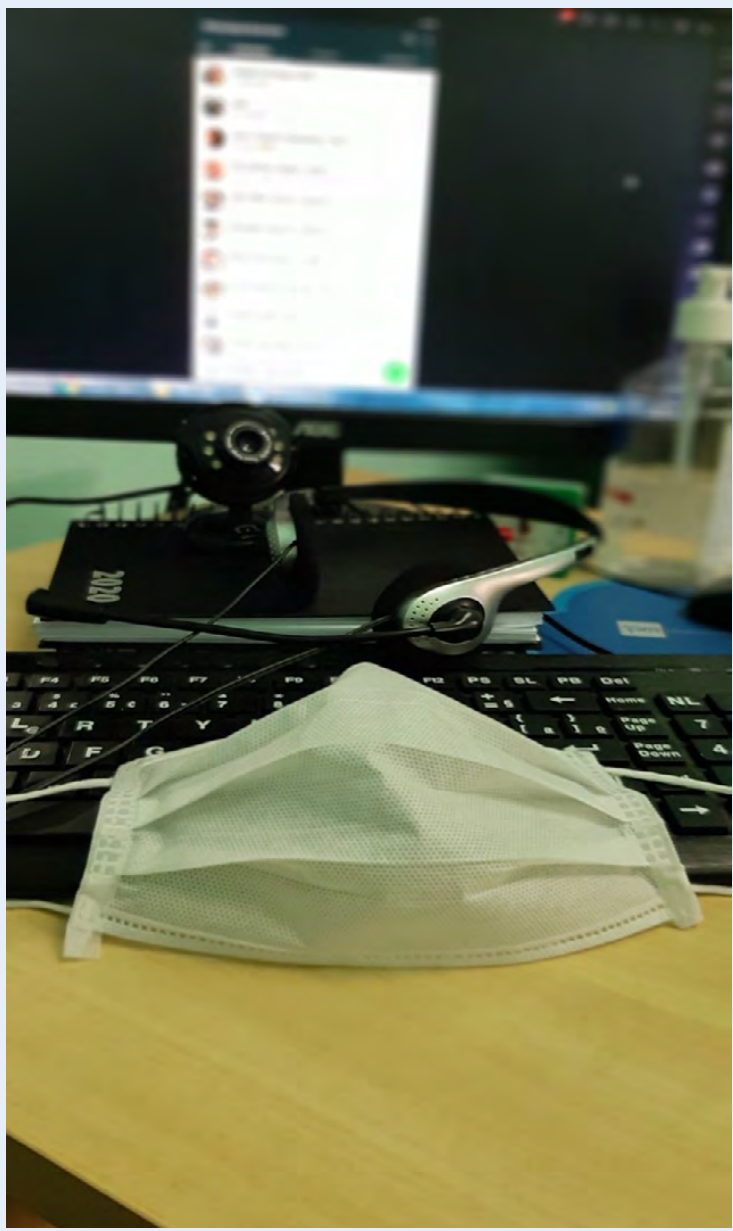

Créditos: Janaína Tápparo Braier.

11 Diante dos desafios e exigências que têm permeado o período pandêmico, registra-se a necessidade de adaptações. Inclui-se aqui o uso de equipamentos de segurança bem como o uso mais frequente das ferramentas de tecnologias, com intuito de manter a oferta dos atendimentos e suporte terapêutico. 